\title{
System Analysis Of Inventory Information On Raw Material Companies
}

\author{
Wahyu Hidayat ${ }^{1}$, Bayu Pramono ${ }^{2}$, Mohhammad Afdulloh $^{3}$ \\ 1,2,3 Universitas Raharja, Jl. Jendral Sudirman No.40 Modernland, Cikokol, Tangerang \\ e-mail:wahyu.hidayat@raharja.info, bayupramono@raharja.info, afdulloh@raharia.info
}

\begin{abstract}
In the era of increasingly rapid development of information technology, the use of computers in every Indonesian company is very important to support information needs. This is definitely mandatory, because with a computerized system all processes ranging from data processing to other important documents can be arranged neatly so that it can facilitate data storage and search. Problems faced in the inventory information system at the company are usually lacking an accurate, fast, and precise information system so that it is less optimal and produces all accurate and relatively long reports. The purpose of the research conducted by the author is to analyze the information system that runs on the raw material company. The methodology used is the system development life cycle approach starting from analyzing the system that runs through UML (Unified Modeling Language) to describe the running system analysis and analysis of the proposed system so as to improve the quality of the standard company.
\end{abstract}

Keywords: Inventory, company, Raw Materials, Management.

\section{Introduction}

Developments in the business world can be characterized by the increasing number of companies engaged in industry, trade and services. Basically an established company has a purpose. The main purpose of a company is how companies can maintain their survival and maintain business continuity in order to survive in competition [1]. In a company, large and small agencies, there is always a supply, especially the inventory of goods to produce, with a good inventory information system that has a profound effect on the development and progress of a company or agency that is mainly engaged in production [2]. Poor inventory information system will affect other aspects, such as lack of consumer or customer trust in the company.

Inventory of goods in raw material companies has a very important role because the operation of the company depends on the availability of raw materials. Similarly, what happened at PT. The Bitung Indonesian Ship Industry that produces ships and company needs. No matter how good the system and procedures for the supply of raw materials carried out in a company without the existence of a controlling role is possible, irregularities will occur that will harm the company [3]. Thus the role of internal control in the company is a concern for interested parties.

The existence of good and regular internal control in managing the inventory of raw materials, the company leaders will obtain reports that are useful to improve the effectiveness of the company, also help in making policy decisions and accountability in leading the company [4]. Internal control of raw material inventories is expected to create control activities for companies that are effective in determining the optimal amount of inventory owned by the company, preventing various violations and frauds that can harm the company, violations of policies applied to inventory, and provide physical security against inventory from theft and damage [5]. In line with the times and the development of the need for information, system design is needed so that the information produced 
meets the needs of the company and can also save time. The development carried out is by designing a stock control material information system, which is expected to provide information easily,quickly and accurately in accordance with the wishes of the user.

\section{Research Method}

In a study, of course, using the method of research to achieve the objectives also get reliable information needed by a researcher to carry out several stages in research. In this study only four (4) stages of the process to be used, i.e., identifying needs, planning, design review and prototype prototype.

Identify needs, by taking a top and down approach to get a design or description of the teaching materials that will be presented on the website later. Furthermore, planning is the stage of analyzing the data that has been obtained from the results of identification needs. Then, Prototype Design is done to adjust between the needs of users and the system that was planned before being implemented in real terms. The last isa Prototype Review, carried out to improve the system if there is a discrepancy with user needs. The following is a list of literature usedin this study.

This paper uses the literature review method, to look for the theoretical basis of previous studies [6] which can be used for problem management. This method is used to gather informationand data from multiple sources (literature), books, and journals for literature relevant to the needs of the writing of this paper [7]. There are 6 (six) literature reviews that are used, there are:

1. Thesis research at FACULTY OF INDUSTRIAL TECHNOLOGY OF AKPRIND YOGYAKARTA SCIENCE \& TECHNOLOGY INSTITUTE conducted by Askin Setia Rinaldy (2009) with the title "COMPUTER PERIPHERAL DATA PROCESSING CLIENT / SERVER SYSTEM AT TOKO MATRIX COMP YOGYAKARTA". The purpose of the study was to design merchandise inventory applications. Applications are designed using visual basic. The inventory system stores a lot of data. Data in this system is managed using a database on a client / server basis, which is designedusing entity diagram concepts and normalization. Communication between units (client / server), starts when the application is running or executed. When the client unit is active, and make transactions. Then the client unit will send a command to the server unit, the server will return the result that the client unit requested. The data that is processed on the server unit is the entire system database, while the one sent to the client is only a single result or data, not the entire database.[8]

2. Research Scientific Journal on the University of Indonesia campus regarding Series technology. MAKARA Technology Series is a scientific journal that provides original articles about research knowledge and information or applications of contemporary research and development related to technology issues. This journal is a publication tool and a forum for sharing research products and developments in the field of technology. Every article for this journal must be sent to the editorial office. Complete information about how to send articles and writing guides is provided in each publication. Each article will undergo a selection process by related experts and or editors. Since 2010 this journal has been published semiannually (June and December). Article publication will not be charged. MAKARA Technology Series is the expansion of MAKARA Series B: Regional Science and Technology as the development of the University of Indonesia MAKARA Research Journal published since January.[9]

3. Thesis research at STMIK Raharja conducted by Widi Nugroho (2007), with the title "Warehouse Spare Parts Inventory Information System Design at PT. KMK Global Sports ". This study discusses the inventory process that is still running using a semicomputer system, but in the storage of data is still not structured because of that there 
is still an error in inputting data because high accuracy is needed so as to minimize errors. In the study, the authors proposed an information system using Visual Basic 6 and Microsoft SQL server 2000 applications.[10]

4. The thesis research at STMIK AMIKOM YOGYAKARTA was conducted by Anita Manik (2010) with the title "ANALYSIS OF THE DESIGN AND IMPLEMENTATIONOF INFORMATION SYSTEMS OF STORES FOR MORNING COFFEE YOGYAKARTA SALES DIVISION." The purpose of this study is to design an application for selling merchandise. Applications are designed using visual basic. The sales system saves a lot of data. Data in this system is managed using Ms.'s database. Access 2003, which was designed using the entity diagram concept and normalization. [11]

5. Thesis research at Gunadarma University conducted by Leonardi Winarsih (2009) with the title "Merchandise Inventory Application Using Visual Basic 6.0". The purposeof this research is to design merchandise inventory applications. Applications are designed using Visual Basic. The inventory system stores a lot of data. Data in this system is managed using a database, which is designed using the concept of entity diagrams and normalization. Tables generated by the database are suppliers, types ofgoods, buy, sell, and customer. Using the inventory section application can manage inventory printing reports directly.[12]

6. Research conducted by Untung Rahardja, By Sholeh, and Fitria Nur setianingsih with the title "USE OF DASHBOARD TO CONTROL PERFORMANCE OF EMPLOYEE ATTENTION TO IMPROVE EMPLOYEE PROFESSIONALISM IN PT .SINARMAS LAND PROPERTY". In this study, it was explained that the use of dashboards that provide information on employee absenteeism can be used to make employees to work together to achieve the success of the company's business. The data displayed in the dashboard is in the form of interactive graph so that the graph can be performedfrom attendance from its employees.[13]

From the 6 (six) literature studies above, the author gained knowledge about the scope of research, starting from the method to the writing of research reports. But through this research, the author wants to explain the variety of studies that can be seen from several perspectives, which can be used as references or used in the management of other researchers' problems.

\section{Results and Analysis}

\subsection{Problem Analysis}

The system and stock control material process that is currently running in a company has been running well but still requires a long time, the warehouse clerk must control the amount of material in the warehouse at any time. While the presentation of stock control material report data must always be updated with its physical inventory. Besides that, the recording of stock control material data still uses Microsoft Excel which causes frequent recording errors and takes a long time because it has to open a lot of other data.

From the problems that have been explained, it can be concluded clearly the lack and advantages reflected in the mind map. 


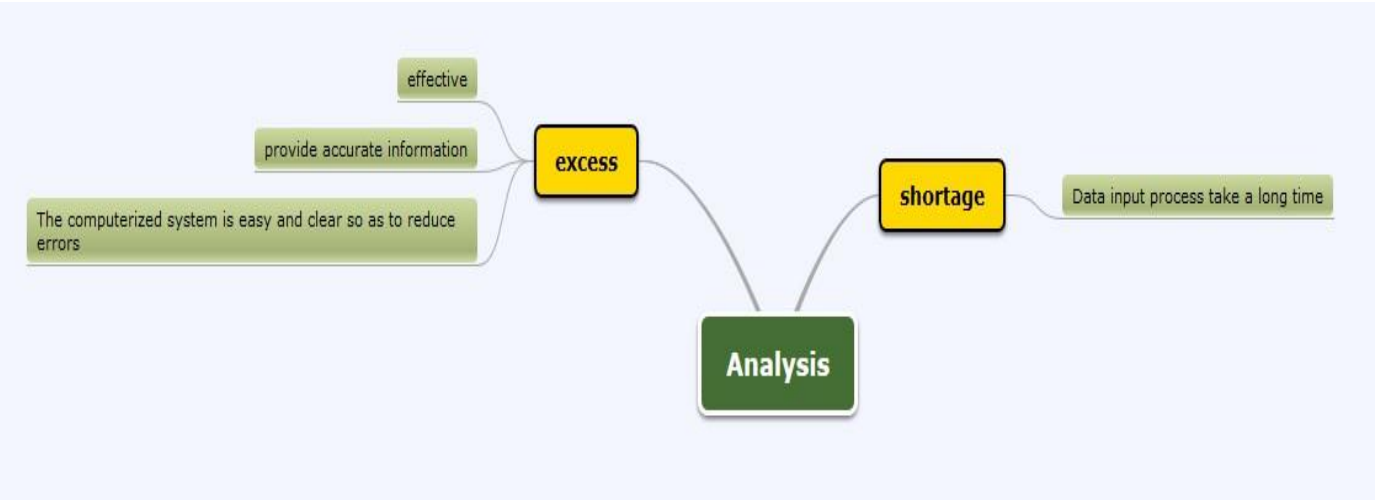

Figure 1. Mind Mapping Analysis

Explained in the picture above which is an analysis of the inventory system that exists in a company. With this, the company is expected to meet the company's needs and also save time and is easier, faster and more accurate.

\subsection{The analysis of the deficiency of the system}

Based on the analysis conducted by the researcher, a data presented will be wrong if the warehouse admin or warehouse leader does not perform a procedure control so that there is less cooperation. This is because the production person who will take the goods sometimes does not make a letter of goods and is not known by the warehouse clerk with this Lack of control for warehouse material.

1. below there are shortcomings that occur in the company:

2. The data input process that occurs in material acceptance reports still takes a long time because it still uses Microsoft Excel.

3. The length of the process of making stock control material reports so that the data needed by the leadership becomes slow.

\subsection{Needs Analysis System}

Based on the analysis of the problems on the system that runs requires a longer time in inputting data and reports produced because the system is still using Microsoft Excel so that the time requires more time to produce a report needed by the leadership.

So by designing a computerized system in the hope that it can help officers in inputting and will reduce errors or obstacles that occur, then the system needs to be:

a. Can display reports and print in Microsoft Excel for data on receipt and expenditure of material from input results so that officers do not need to make reconciliation in making reports.

b. Computerized system that can control easily and clearly, thus reducing errors that occur.

c. Can provide accurate information so that information can be useful by officers and leaders.

d. Can add new data or change data, so that the system can be fixed immediately if there are errors in inputting or not inputted.

\subsection{Solutions}

With the construction of a system that is needed by users by using visual-based applications because visual-based applications are familiar among community agencies. with a web-based 
system, web-based applications allow users to use data together at the same time. so that the system can be run on any operating system, and does not require high computer specifications to be able to use web-based applications.

\section{Conclusion}

B Based on the results of research conducted on the inventory information system in raw material companies, the research can draw conclusions as follows:

1. The system that runs at this time has not been able to facilitate employees in obtaining information, this is due to the length of the search process and the making of the report, because of the large number of documents needed, so the decision-making process becomes hampered.

2. To design a computerized stock control material information system, which can facilitate stakeholders in producing reports needed for the decision making process by the warehouse head so that they can solve existing problems

3. The stock control material information system that is running still uses Ms. Excel starts from material acceptance from suppliers, taking material to production to produce material stock control reports. this causes delays in the processing of data, causing the information generated to be inaccurate.

\section{References}

[1] Yustianti. 2012. Komponen Sistem Informasi. Yogyakarta: Andi

[2] Sutabri. 2012. Konsep Dasar Informasi. Yogyakarta: Andi

[3] Lili Tanti 2009. Pengembangan Perangkat Ajar Berbantuan Komputer Untuk MempelajariTata Bahasa Inggris. Jurnal CCIIT Vol. 3 No.2- Januari 2009: Tangerang

[4] Maimunah. 2012. Media Company Profile Sebagai Sarana Penunjang Informasi dan Promosi. Jurnal CCIT Vol.5 No.3- Mei 2012. Tangerang : Perguruan Tinggi Raharja

[5] Gordon B. Davis. 2012. Nilai Informasi dikatakan sempurna apabila perbedaan antara kebijakan optimal, tanpa informasi yang sempurna.Universitas Of Minnesota

[6] Wibowo, R. A. (2009). Sistem Informasi Persediaan Keluar Masuk Barang Pada Inside Distro Jakarta. Speed-Sentra Penelitian Engineering dan Edukasi, 1(4).

[7] Wijaya, A., Arifin, M., \& Subiyanto, T. (2013). Rancang Bangun Sistem InformasiPerencanaan Persediaan Barang. Jurnal JSIKA, 2(1), 14-20.

[8] Supriyanti, D., Romadhon, Y. B., \& Iskandar, D. (2015). SISTEM INFORMASI PERSEDIAAN BARANG PADA PT. HANKOOK CERAMIC INDONESIA. CERITA Journal, 1(1), 56-63.

[9] Losonczy, A., Makara, J. K., \& Magee, J. C. (2008). Compartmentalized dendritic plasticity and input feature storage in neurons. Nature, 452(7186), 436.

[10] Supriyanti, D., Romadhon, Y. B., \& Iskandar, D. (2015). SISTEM INFORMASI PERSEDIAAN BARANG PADA PT. HANKOOK CERAMIC INDONESIA. CERITA Journal, 1(1), 56-63.

[11] RAMDANI, N. (2013). ANALISIS SISTEM INFORMASI AKUNTANSI PENJUALAN KAMAR DAN PENERIMAAN KAS PADA HOTEL RANGGONANG SEKAYU (Doctoral dissertation, Universitas Muhammadiyah Palembang).

[12] Yulianto, H. D., Fauziah, S., \& Widilestariningtyas, O. (2012). "SISTEM INFORMASI AKUNTANSI PERSEDIAAN BARANG DAGANG PADA PT TASLY WORLD INDONESIA CABANG BANDUNG". Jurnal Riset Komputerisasi Akuntansi, 1(1), 97-111.

[13] Rahardja, U., Sholeh, O., \& Nursetianingsih, F. (2015). Penggunaan Dashboard untuk Mengontrol Kinerja Absensi Pegawai Guna Meningkatkan Profesionalisme Pegawai pada PT. Sinarmas Land property. SEMNASTEKNOMEDIA ONLINE, 3(1). 